\title{
Effects of Recycled Aggregate Resin (RAR) in Concrete Material
}

\author{
Sharifah Salwa Mohd Zuki ${ }^{1 *}$ Shahiron Shahidan ${ }^{1}$, Shivaraj Subramaniam ${ }^{1}$ \\ ${ }^{1}$ Jamilus Research Center (JRC)-Sustainable Construction, Faculty of Civil Engineering and Built Environment, \\ Universiti Tun Hussein Onn Malaysia, Batu Pahat, 86400 Johor, MALAYSIA
}

*Corresponding Author

DOI: https://doi.org/10.30880/ijscet.2020.11.02.006

Received 30 July 2020; Accepted 30 August 2020; Available online 02 September 2020

\begin{abstract}
This paper discussed the recycled aggregates produced from construction and demolition waste and their utilization in concrete construction. Along with a brief overview of the engineering properties of recycled aggregates, the paper also summarizes the effect and use of recycled aggregates on the properties of fresh and hardened concrete. The recycled aggregates were treated with epoxy resin to reduce the water absorptions with different percentages of resin such as $0 \%, 25 \%, 50 \%, 75 \%$, and $100 \%$. Epoxy resin is widely used in recent years owing to the enhancing of mechanical and durability of the concrete. This research also showed, recycled aggregate concrete are close proximity to normal concrete in terms of split tensile strength, compression strength and wet density. The low usage of resin was obtained good strength concrete compared to high percentage contained treated aggregates due to low bonding between material.
\end{abstract}

Keywords: Epoxy Resin, Recycle Aggregate, Concrete, Bonding

\section{Introduction}

Using the waste concrete construction as aggregates to produce the new recycled concrete is an important development direction in construction materials and for environmental protection (Pepe et al. 2016; Pandurangan et al. 2016; Shahidan et al. 2013; Md Nor et al. 2011; Kudus et al. 2012; Shahidan et al. 2011; Shahidan et al. 2017). According to Silva et. al., (2018), 2008 European legislation in Directive 2008/98/EC aims that by 2020 a minimum of $70 \%$ by weight of all non-hazardous and non-natural construction and demolition waste (CDW) should be reuse and recycled (Silva, de Brito \& Dhir, 2018). Whereas, in Hong Kong, 37,000 tonnes of CDW were produced daily, hence the government adopted a policy to support any innovative programmes that promotes the use of recycled aggregates (Poon et al. 2004). Extensive researches had been done regarding recycled aggregates, however, practitioners still unsure due to several reasons such as limited existing standards and specification regarding the effects of recycled aggregates on the performance of concrete (Silva, de Brito \& Dhir, 2018: Tam, Soomro \& Evangelista, 2018).

Recycled aggregates are normally having high water absorption rate as compared to natural aggregate (Knaack \& Kurama, 2012: Barbuta, Harja \& Baaran, 2010; Qasrawi, Marie \& Tantawi, 2013; Ramlan et al., 2020). In some cases, the used of plasticizer is needed in order to increase the workability of the concrete mixed containing recycled aggregates (Ahmad, Tech \& Singh, 2016). Matias et al. (2013) added high performance super plasticizer in concrete mixes with $25 \%$ and $100 \%$ replacement ratio and it was observed that slump increased about $7.31 \%$ and $25.80 \%$, respectively. In addition, by adding water repellent agent such as saline increased slump of recycled aggregates concrete up to $75 \%$ (Zhu et al. 2013). 
Moisture content of recycled aggregates may also have an effect on the concrete strength properties (Hansen \& Hedegard, 1984; Wan Ibrahim et al. 2014; Ali et al. 2016; Buck, 1977; Abdul Rahim et al. 2014). The effect of moisture content of recycled aggregates on fresh and hardened concrete is similar to the effect of moisture content natural aggregates (Shahidan, Isham \& Jamaluddin, 2016). Based on review by Silva, de Brito \& Dhir (2018), there were two methods that can be used in order to achieve equivalent workability levels as natural aggregates, i.e., the presaturation approach and water compensation during mix. The letter showed much better track history. However, there were some issues regarding this method since the water absorption rate depends on recycled aggregates absorption capacity and size. The inability of recycled aggregates to absorb water faster will lead to initial slump levels that equivalent to control concrete. As the recycled aggregates absorb more water with time, the workability will also reduce with time Silva, de Brito \& Dhir (2018). Beltran et al. (2014) conducted a study where with increment of recycled aggregates, certain amount of cement was added into the mix in order to obtain equivalent slumps and compressive strength. For $100 \%$ replacement of recycled aggregates, $12 \%$ more cement was added to maintain the slumps and compressive strength. Even though extra cement can cater for the decrement in workability and compressive strength caused by increased percentage of recycled aggregates, extra cement leads to less economic and environmental friendly approach.

Density depends on the type of aggregates grade used, the moisture content and the mix proportions (Shahidan et al. 2011). The density of recycled aggregates was observed to be lower than natural aggregates (Kou \& Poon, 2009). The difference between recycled aggregates and natural aggregates is the presence of adhered mortar. Therefore, low density in recycled aggregates were contributed by low specific gravity of mortar that adhered on the surface of these aggregates (Kou \& Poon, 2009). According to Wagih et al. (2013), recycled aggregates possess low density due to its high porosity than natural aggregates. Again, high porosity of recycled aggregates concrete can be attributed to the presence of adhered mortar.

In a review by Kisku et al. (2017), compressive strength of recycled aggregates concrete with similar water-cement ratio (c/w ratio) decreased with increased percentage of recycled aggregates replacement. In general, the percentages of decrement is around $10 \%$ of compressive strength of concrete with natural aggregates. However, some researcher reported that the compressive strength of recycled aggregates concrete remains unaffected or slightly increased for replacement up to $25 \%$ Kisku et al. (2017). This due to good grading of recycled aggregates. It was also reported that $100 \%$ replacement of recycled aggregates lead to $50 \%$ increase in standard deviation of the samples. And this can be attributed to heterogeneity nature of recycled aggregates.

Split tensile strength of recycled aggregates depends on variety of factors such as percentage of replacement, water-binder ratio, mixing methods, type of cement used in the mix, curing age and quality of recycled aggregates Kisku et al. (2017). There were contradictory finding on tensile strength of recycled aggregates concrete as reported by Kisku et al. (2017). The first one was tensile strength of recycled aggregates concrete were 6\%, 10\% and $40 \%$ less than the tensile strength of normal concrete when the percentage of replacement were $25 \%, 50 \%$ and $100 \%$. Contrary, studies by Fonseca, de Brito \& Evangelista, 2011 and Pereira, Evangelista \& de Brito, 2012 reported that tensile strength of recycled aggregates concrete remain the same and some even exceeded the tensile strength of normal concrete when replacement of recycled aggregates were limited to not more than $30 \%$. In addition, the tensile strength improved as the curing age of recycled aggregates concrete increased. However, this only true for replacement up to $50 \%$ of recycled aggregates. Higher replacement ratio results in almost similar values of tensile strength (Fonseca, de Brito \& Evangelista, 2011).

Adhered mortar were one of the main problem when dealing with recycled aggregates. The presence of adhered mortar was believed to be the main reason for strength reduction in recycled aggregates concrete (Saravanakumar, Abhiram \& Manoj, 2016). Furthermore, adhered mortar forms weak interfacial transition zone that leads to cracks in concrete. In order to minimize the effect of adhered mortar, recycled aggregates needed to go through treatment. According to Saravanakumar, Abhiram \& Manoj, 2016, there were three type of treatment; (1) mechanical treatment (i.e., ultrasonic cleaning, ball milling), (2) chemical treatment (i.e., presoaking recycled aggregates in acidic environment) and (3) thermal treatment (i.e., heating the recycled aggregates). However, in recent years many research studies on epoxy resin have been conducted. The researchers observed that epoxy resin enhanced the mechanical and durability of the concrete (Tabatabaeian et al., 2019). In addition, Fernandez-Ruiz et al., (2018) observed that the presence of epoxy resin improved bond, strength, impermeability, chemical resistance as well as durability of both mortar and concrete.

Objective of this research is to determine the fresh and hardened properties of recycled aggregates concrete and the optimum percentage of resin treated recycled aggregates concrete.

\section{Recycled Aggregates}

Crushed aggregate from either demolition concrete or from hardened leftover concrete can be regarded as an alternative coarse aggregate (Shahidan et al. 2016; Ramlan et al., 2020). The use of 100\% recycled coarse aggregate in concrete, unless carefully managed and controlled, is likely to have a negative influence on most concrete properties 
such as compressive strength, modulus of elasticity, shrinkage and creep, particularly for higher strength concrete (Rao \& Jha, 2007; Hansen \& Narud, 1983).

The sources of material from which a recycled aggregate came are unknown and the variability and strength of the recycled aggregate concrete (Ho et al. 2013; Vegas et al. 2015). Recycled aggregate concrete can be manufactured using recycled aggregate at $100 \%$ coarse aggregate replacement where the parent concrete were processing of the recycled aggregate and the manufacture of the recycled aggregate concrete are all closely controlled (Salleh, Mohd Sam \& Mohd Yatim, 2015). However as target strengths increased, the recycled aggregate can limit the strength, requiring a reduction in recycled aggregate replacement (Sharma and Singla, 2014; Benge, Pena \& Ortiz, 2010; Yaqub \& Bukhari, 2007). Table 1 presented the physical properties of recycle aggregates.

Table 1 - Physical properties of recycled aggregates (Qasrawi, Marie \& Tatawi, 2013)

\begin{tabular}{lc}
\hline Physical property & Recycled aggregates concrete \\
\hline Nominal Max.Size (mm) & 20 \\
Fineness modulus & 6.79 \\
Bulk Density $\left(\mathrm{kg} \cdot \mathrm{m}^{-3}\right)$ & 1250 \\
Saturated surface dry specific & gravity \\
Oven-dry specific gravity & 2.53 \\
Porosity (vol. (\%)) & 2.48 \\
Absorption (wt. (\%)) & 5.03 \\
Moisture content (wt. (\%)) & 2.03 \\
Angularity number & 1.57 \\
Aggregate impact value (wt. $(\%))$ & 9.50 \\
\hline
\end{tabular}

\section{A. Resin}

Epoxy resin (Sika Floor 161-HC) is typically used in applications such as the aerospace industry and motor racing to takes the higher end of the performance spectrum. Some epoxies are cured at ambient temperatures, thus giving a reduction in production costs. Such epoxy resins are of particular interest in structural engineering applications, due to their structural performance and durability (Qasrawi, Marie \& Tantawi, 2013; Gamashta \& Gumashta, 2006).

As mention previously, recycled aggregates possess high water absorption rate, therefore epoxy resin was used in this research to coat the aggregates surface. Hence minimizing the water absorption and improved the workability of concrete mixes. Table 2 shows the physical properties of epoxy resin used in this research.

Table 2 - Physical properties of epoxy resin (Sika Floor 161-HC)

\begin{tabular}{lc}
\hline Properties & Epoxy \\
\hline Viscosity at $250(\mathrm{cP})$ & $12,000-13,000$ \\
Density $\left(\mathrm{g} / \mathrm{cm}^{3}\right)$ & 1.16 \\
Heat distortion temperature $\left({ }^{\circ} \mathrm{C}\right)$ & 100 \\
Elastic modulus $(\mathrm{GPa})$ & 5.0 \\
Flexure strength $(\mathrm{MPa})$ & 60 \\
Tensile strength $(\mathrm{MPa})$ & 73 \\
Maximum elongation $(\%)$ & 4 \\
\hline
\end{tabular}

\section{Laboratory Works}

Treated recycled aggregates percentages used in this study were $0 \%, 25 \%, 50 \%, 75 \%$, and $100 \%$. Total of 75 samples with size $100 \mathrm{~mm}$ x $100 \mathrm{~mm}$ x $100 \mathrm{~mm}$ (60 cubes) and $150 \mathrm{~mm}$ x $200 \mathrm{~mm}$ (15 cylinders) were prepared using different percentage of resin. The samples were tested for 7 and 28 days (

Table 3). All the specimens were tested with fresh and hardened stated of concrete using splitting tensile test, compressive strength and water absorption. A general understanding for the task involved was important and planning of activities was done accordingly (ASTM C131, 2006; ASTM C496/C496 M, 2011; ASTM C33/C33 M, 2013). 
Table 3 - Number of sample tested

\begin{tabular}{cccc}
\hline $\begin{array}{c}\text { Percentage of treated } \\
\text { recycled aggregates }(\boldsymbol{\%})\end{array}$ & \multicolumn{2}{c}{ Number of cube sample } & Number of cylinder sample \\
$\mathbf{7}$ days & 6 & $\mathbf{2 8}$ days & 28 days \\
\hline 0 & 6 & 6 & 3 \\
25 & 6 & 6 & 3 \\
50 & 6 & 6 & 3 \\
75 & 6 & 6 & 3 \\
100 & 6 & 6 & 3 \\
\hline
\end{tabular}

\section{A. Recycled Aggregates Preparation}

Concrete wastes were collected from laboratory. All the wastes were put into crushing machine to crush into small pieces. Crushed concrete then sieved to maximum size of $20 \mathrm{~mm}$. the crushing machine was equipped with sieving panels. The process of preparing the recycled aggregates is shown in Fig. 1.

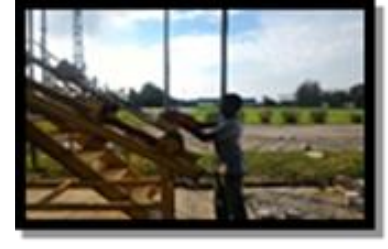

(a)

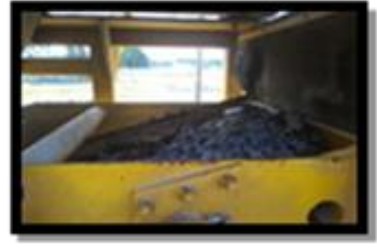

(c)

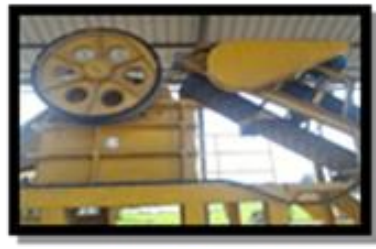

(b)

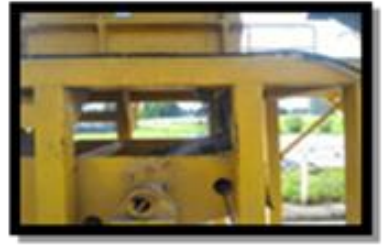

(d)

Fig. 1 - Recycle aggregates process: (a) Concrete wastes were transferred into machine; (b) Concrete wastes were transferred by conveyer; (c) Crushing process; (d) Crushed aggregates were sieved

\section{B. Recycled aggregates treatment}

Recycled aggregates were treated using epoxy resin. The mix ratio of resin and hardener used was 4:1. The treated aggregates were dried for 24 hours. The treatment process of recycled aggregates is shown Fig. 3.

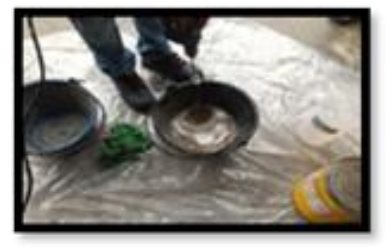

a)

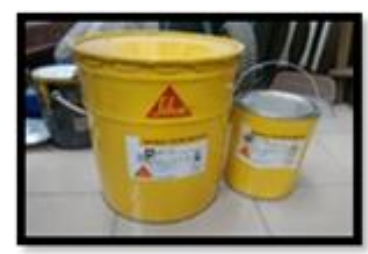

c)

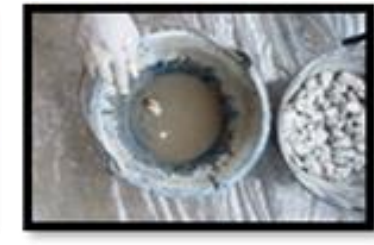

b)

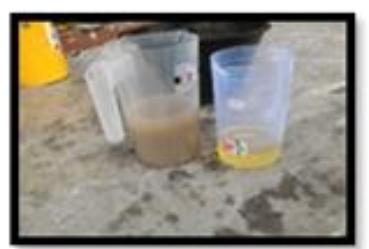

d)

Fig. 2 - Recycled Aggregates treatment : (a) Epoxy resin; (b) Ratio 4:1 used for resin and hardener; (c) Resin and hardener were mixed together; (d) 


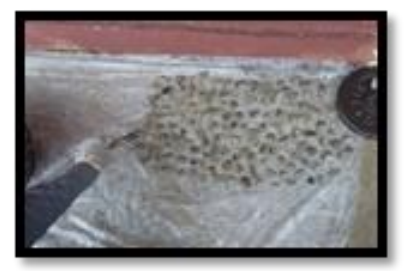

e)

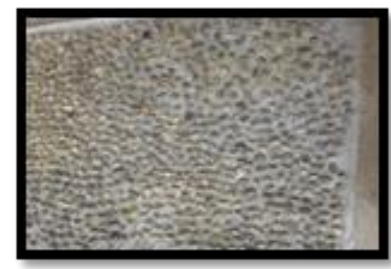

f)

Fig. 3 - Recycled Aggregates treatment : (e) The soaked aggregates were putted in plastic; (f) Aggregates leaved to dried for 24 hours. (Cont...)

\section{Result and discussion}

\section{A. Slump test}

Fig. 4 shows the slump test result. The slump were design to be in the range of $30-60 \mathrm{~mm}$. From Fig. 4 and

Table 4, the slump increased with percentages of treated recycled aggregates. The presence of epoxy resin that coats the outer layer of recycled aggregates were able to prevent excessive absorption of free water during mixes. However, epoxy resin alter the physical appearance of the recycled aggregates into smooth and angular surface. Therefore, increment in percentage of recycled aggregates into the mixes leads to less friction between aggregates. Thus, making the recycled aggregates slide easily during the slump test (high slump value). Nevertheless, the slump for all mixes still fall within the designed range which is $30-60 \mathrm{~mm}$.

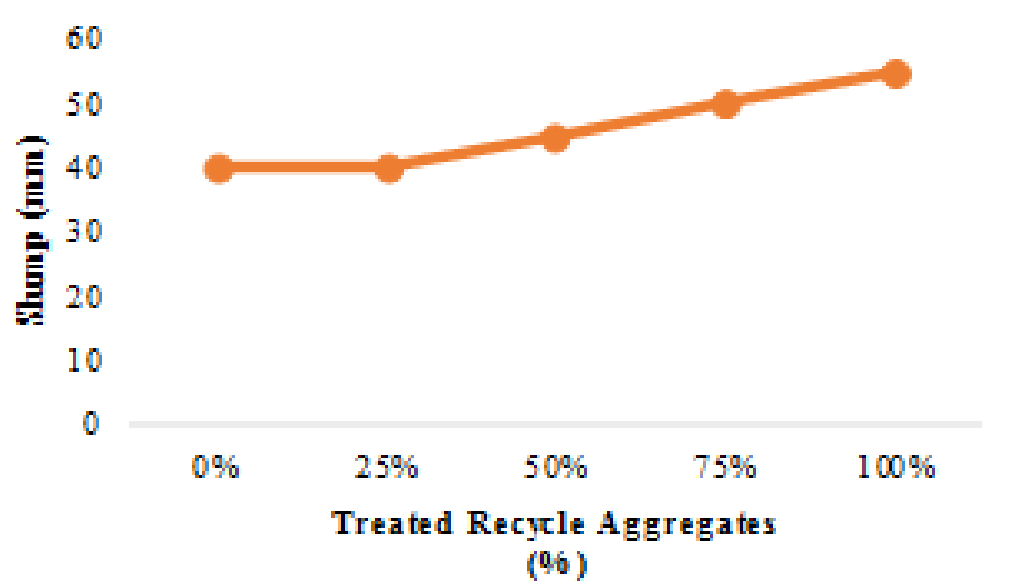

Fig. 4 - Slump test results

Table 4 - Slump test result

\begin{tabular}{cc}
\hline Replacement percentages (\%) & Slump (mm) \\
\hline 0 & 40 \\
25 & 40 \\
50 & 45 \\
75 & 50 \\
100 & 55 \\
\hline
\end{tabular}

\section{B. Split tensile test}

Fig. 5 and Table 5 show that the $25 \%$ of recycled aggregates has obtained highest tensile strength value of 2.14Mpa compared with others. As the percentages of replacement increased, tensile strength decreased. This can be 
associated with porous microstructure of recycled aggregates concrete that made the recycled aggregates concrete breaks easily under small pressure. Hence, this finding supported findings by Fonseca, de Brito \& Evangelista, (2011) and Pereira, Evangelista \& de Brito, (2012).

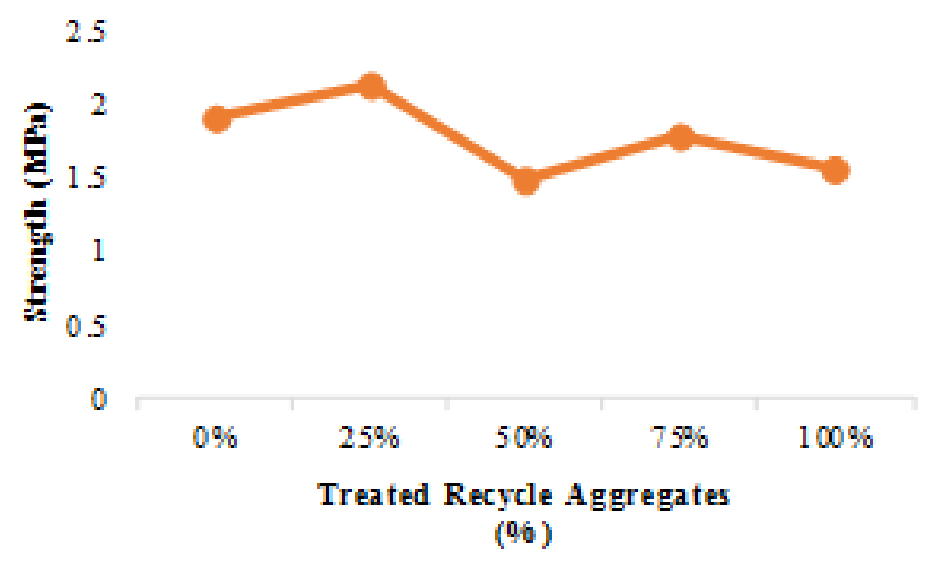

Fig. 5 - Split tensile test results

Table 5 - Split tensile strength result

\begin{tabular}{cc}
\hline Replacement percentages $(\%)$ & 28 days average strength (MPa) \\
\hline 0 & 1.90 \\
25 & 2.14 \\
50 & 1.48 \\
75 & 1.79 \\
100 & 1.57 \\
\hline
\end{tabular}

\section{Compression test}

Compressive strength was conducted by using Universal Testing machine (UTM) that was available at Faculty of Civil and Environmental Engineering (FKAAS), UTHM (Fig. 7). In general, compressive strength of treated recycled aggregates concrete decreased with increased replacement percentages. However, highest compressive strength is $38.8 \mathrm{MPa}$ for $25 \%$ of recycled aggregates replacement (Fig. 6 and Table 6). There is $10 \%$ decrement in compressive strength when compared to control concrete. Treating the recycled aggregates with epoxy resin smoothen the surface of the aggregates. It benefitted in preventing the aggregates from absorbing the free water. However, the smoothen surface weakened the bond between aggregates thus reducing the compressive strength. Nevertheless, the compressive strength of $25 \%$ recycled aggregates replacement still achieved targeted strength of 30MPa.

Control concrete had highest compressive strength due to better interfacial bond between aggregates and cement paste. In addition, better interlocking of natural aggregates were obtain because of the angular shape of the aggregates.

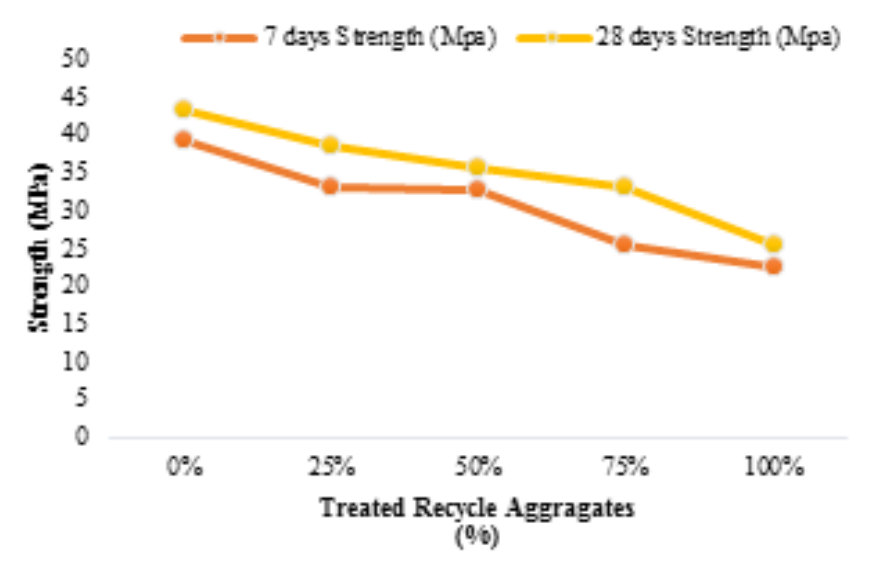


Fig. 6 - Compression test results

Table 6 - Compression test result

\begin{tabular}{ccc}
\hline Replacement percentages (\%) & 7 days (MPa) & 28 days (MPa) \\
\hline 0 & 39.4 & 43.3 \\
25 & 33.1 & 38.8 \\
50 & 33.0 & 35.8 \\
75 & 25.6 & 33.1 \\
100 & 22.7 & 25.7 \\
\hline
\end{tabular}

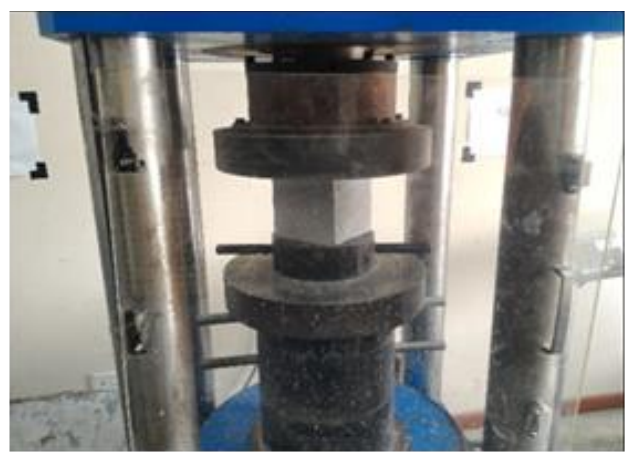

Fig. 7 - Compression test

\section{Water absorption test}

Fig. 8 and Table 7 indicated that control concrete obtained higher water absorption rate at 5.5\% for 7 days compared to recycled aggregates concrete. However, $100 \%$ recycled aggregates concrete obtained the lowest water absorption at $1.4 \%$. Generally, as the percentage of replacement increased the water absorption rate decreased. Hence, epoxy resin successfully reduced the water absorption rate of recycled aggregates. All pores in recycled aggregates concrete are completely filled with resin, therefore water absorption rate is lower compared to control concrete. Control concrete absorb more water due to its porous surface.

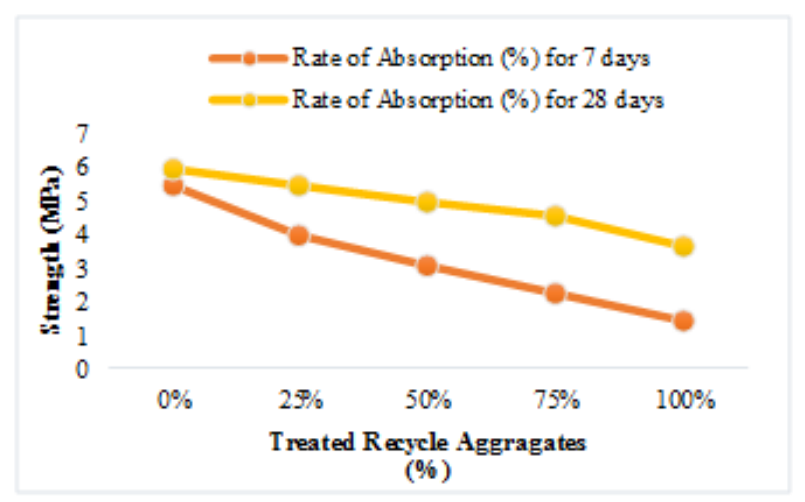

Fig. 8 - Water absorption test results

Table 7 - Water absorption result

\begin{tabular}{ccc}
\hline Replacement percentage (\%) & $\mathbf{7}$ days $(\%)$ & 28 days $(\%)$ \\
\hline 0 & 5.5 & 6.0 \\
25 & 4.0 & 5.5 \\
50 & 3.1 & 5.0 \\
75 & 2.3 & 4.6
\end{tabular}




$100 \quad 3.7$

\section{Conclusion}

Based on the result of a slump test, it can be said that slump of recycled aggregates concrete increased with increased percentages of recycled aggregates. However, the slump value was still in the designed range.

As for compression test, control concrete obtained compressive strength of $43.3 \mathrm{MPa}$. Whereas, the highest compressive strength achieved by recycled aggregates concrete is $38.8 \mathrm{MPa}$ with $25 \%$ replacement. This is due to treating recycled aggregates with epoxy resin makes aggregates smoother which cause reduction of concrete material bonding in concrete. Meanwhile control concrete have better interfacial bond between aggregate and cement paste that caused high strength in compression test.

For the split tensile test, recycled aggregates concrete with $25 \%$ replacement obtained highest strength and even exceeded the tensile strength of control concrete. This result is supported by many other researchers where $25 \%$ replacement of recycled aggregates enhance the tensile strength of the concrete. However, further increment of recycled aggregates seems to eliminate this effects.

Based on compressive and tensile strength test, it can be concluded that $25 \%$ replacement of recycled aggregates are the optimum replacement percentage. Coating recycled aggregates with epoxy resin were able to prevent high water absorption rate. However, the presence of epoxy resin did not alter the strength (compressive and tensile strength) of the recycled aggregates concrete.

\section{Acknowledgement}

The authors would like to thank Universiti Tun Hussein Onn Malaysia Tier 1 Grant H185. The authors also would like to express gratitude to all technical staff at Faculty of Civil Engineering and Built Environment for their technical helps and support.

\section{References}

Abdul Rahim, M., Ibrahim, N. M., Idris, Z., Ghazaly, Z. M., Shahidan, S., Rahim, N. L., Sofri, L. A., \& Isa, N. F. (2014). Properties of Concrete with Different Percentange of the Rice Husk Ash (RHA) as Partial Cement Replacement. Materials Science Forum, 803, 288-293

Ahmad, S., Tech, W. M., \& Singh, B. (2016). Shear transfer strength of normal and high-strength recycled aggregate concrete - An experimental investigation. Construction Building Materials, 125, 29-40

Ali, N., Yaacob, K. Y., Shahidan, S., \& Abdullah, S. R. (2016). Investigation of Compressed Earth Brick Containing Ceramic Waste. ARPN Journal of Engineering and Applied Sciences, 8(11), 5459-5462

ASTM International (2006). Standard test method for resistance to degradation of small-size coarse aggregate by abrasion and impact in the Los Angeles machine. West Conshohocken: ASTM C131

ASTM International (2011). Standard test method for splitting tensile strength of cylindrical concrete specimens. West Conshohocken: ASTM C496/C496 M

ASTM International (2013). Standard specification for concrete aggregates. West Conshohocken: ASTM C33/C33. M

Barbuta, M., Harja, M., \& Baaran, I. (2010). Comparison of mechanical properties for polymer concrete with different types of filler. Journal of Materials in Civil Enginee ring, ASCE, 22(7), 696-701

Beltran, M. G., Barbudo, A., Agrela, F., Galvin A. P., \& Jimenez, J. R. (2014). Effect of cement addition on the properties of recycled concretes to reach control concrete strength. Journal of Cleaner Production, 79, 124-133

Benge, J., Pena, J., \& Ortiz, I. (2010). Influence of Recycled Aggregates on Mechanical Properties of High Performance Concrete. Retrieved on July 05, 2018 from http://ilin.asee.org

Buck, A. D. (1977). Recycled concrete as a source of aggregate. ACI Journal, 74 (5), 212-219

Fernandez-Ruiz, M.A., Gil-Martin, L.M., Carbonell-Marquez, J.F., \& Hernandez-Montes, E. (2018). Epoxy resin and ground tyre rubber replacement for cement in concrete: Compressive behavior and durability properties. Construction and Building Materials, 173, 49-57 
Fonseca, N., de Brito, J., \& Evangelista, L. (2011). The influence of curing conditions on the mechanical performance of concrete made with recycled concrete waste. Cement and Concrete Composites, 33, 637-643

Gamashta, L., \& Gumashta, S. (2006). Reuse of Concrete and Masonry Waste Materials in Construction to Minimize Environmental Damages Due to Quarrying. Journal of Environmental Research and Development, 1(1), 65-67

Hansen, T. C., \& Hedegard, S. E. (1984). Properties of recycled aggregate concrete as affected by admixtures in original concretes. ACI Journal, 81 (1), 21-26

Hansen, T. C., \& Narud, H. (1983). Strength of recycled concrete made from crushed concrete coarse aggregate. Concrete International, 1(5), 79-83

Ho, N. Y., Lee, Y. P. K., Lim, W. F., Zayed, T., Chew, K. C., Low, G. L., \& Ting, S. K. (2013). Efficient Utilization of Recycled Concrete Aggregate in Structural Concrete. Journal of Materials in Civil Engineering, 3(25), 19435533.0000587

Kisku, N., Joshi, H., Ansari, M., Panda, S. K., Nayak, S. \& Dutta, S. C. (2018). A critical review and assessment for usage of recycled aggregates as sustainable construction material. Construction Building Materials, 13, 721-740

Knaack, A. M., \& Kurama, Y. C. (2012). Rheological and mechanical behavior of concrete mixtures with recycled concrete aggregates. Structural Congress 2012, 2257-2267

Kou, S. C., \& Poon, C. S. (2009). Properties of self-compacting concrete prepared with coarse and fine recycled concrete aggregates. Cement and Concrete Composite, 31, 622-627

Kudus, S. A., Bunnori, N. M., Basri, S. R., Shahidan, S., Jamil, M. N. M., \& Noor, N. M. (2012). An Overview Current Application of Artificial Neural Network in Concrete. Advanced Materials Research, 626, 372-375

Matias, D., de Brito, J., Rosa, A., \& Pedro, D. (2013). Durability of concrete with recycled coarse aggregates: influence of super plasticizers. Journal of Materials in Civil Engineering, 26, 06014011

Md Nor, N., Muhamad Bunnori, N., Ibrahim, A., Shahidan, S., \& Saliah, S. N. M. (2011). An investigation on acoustic wave velocity of reinforced concrete beam in-plane source. 2011 IEEE 7th International Colloquium on Signal Processing and Its Applications, 19-22

Pandurangan, K., Dayanithy, A., \& Prakash, S. O. (2016). Influence of treatment methods on the bond strength of recycled aggregate concrete. Construction Building Materials, 120, 212-221

Pepe, M., Dias, R., Filho, T., Koenders, E. A. B., \& Martinelli, E. (2016). A novel mix design methodology for Recycled Aggregate Concrete. Construction Building Materials, 122, 362-372

Pereira, P., Evangelista, L., \& de Brito, J. (2012). The effect of super plasticizers on the mechanical performance of concrete made with fine recycled concrete aggregates. Cement and Concrete Composites, 34, 1044-1052

Poon, C. S., Shui, Z. H., Lam, L., Fok, H., \& Kou, S. C. (2004). Influence of moisture states of natural and recycled aggregates on the slump and compressive strength of concrete. Cement and Concrete Research, 34, 31-36

Qasrawi, H., Marie, I., \& Tantawi, H. (2013). Use of recycled concrete rubbles as coarse aggregate in concrete. Retrieved on July 05, 2017 from https://www.semanticscholar.org

Ramlan, M.R., Shahidan, S., Zuki, S.S.M, Abdullah, S.R., Ibrahim, M.H.I., \& Rahim, A.A., (2020). Strength and Quality Assessment of Recycled Aggregate and Crumb Rubber Concrete Using the Ultra Pulse Velocity Method. Proceedings of AICCE'19. AICCE 2019. Lecture Notes in Civil Engineering, 53, 799-806

Rao, A., \& Jha, K. N. (2007). Use of aggregates from recycled construction and demolition waste in concrete. Resource, Conservation and Recycling, 1(50), 71-81 
Salleh, N., Mohd Sam, A. R., \& Mohd Yatim, J. (2015). Flexural Behavior of GFRP RC Beam Strengthened with Carbon Fiber Reinforced Polymer (CFRP) Plate: Cracking Behavior. Applied Mechanics and Materials, 752-753, 610616

Saravanakumar, P., Abhiram, K., \& Manoj, B. (2016). Properties of treated recycled aggregates and its influence on concrete strength characteristics. Construction and Building Materials, 111, 611-617

Shahidan, S., Azmi, M. A. M., Kupusamy, K., Zuki, S. S. M., \& Ali, N. (2017). Utilizing Construction and Demolition (C\&D) Waste as Recycled Aggregates (RA) in Concrete. Procedia Engineering, 174, 1028-1035

Shahidan, S., Bunnori, N. M., Md Nor, N., \& Basri, S. R. (2011). Damage severity evaluation on reinforced concrete beam by means of acoustic emission signal and intensity analysis. 2011 IEEE Symposium on Industrial Electronics and Applications, 337-341

Shahidan, S., Isham, I., \& Jamaluddin, N. (2016). A Review on Waste Minimization by Adopting in Self Compacting Concrete. MATEC Web of Conference, 47, 1-7. Shahidan, S., Isham, I., \& Jamaluddin, N. (2016). A Review on Waste Minimization by Adopting in Self Compacting Concrete. MATEC Web of Conference, 47, 1-7

Shahidan, S., Koh, H. B., Alansi, A. M. S., \& Loon, L. Y. (2016). Strength Development and Water Permeability of Engineered Biomass Aggregate Pervious Concrete. MATEC Web of Conference, 47, 2-7

Shahidan, S., Pullin, R., Holford, K. M., Muhamad Bunnori, N., \& Md Nor, N. (2013). Quantitative Evaluation of the Relationship between Tensile Crack and Shear Movement in Concrete beams. Advanced Materials Research, 626, 355359

Sharma, J., \& Singla, S. (2014). Influence of recycled concrete aggregates on Strength parameters of concrete. International Journal of Civil Engineering, 4, 20-24

Silva, R. V., de Brito J., \& Dhir, R. K. (2018). Fresh-state performance of recycled aggregate concrete: A review. Construction and Building Materials, 178, 19-31

Tabatabaeian, M., Khaloo, A., \& Khaloo, H. (2019). An innovative high performance pervious concrete with polyester and epoxy resin. Construction and Building Materials, 228, 116820

Tam, V. W. Y., Soomro, M., \& Evangelista, A. C. J. (2018). A review of recycled aggregates in concrete application (2000 - 2017). Construction and Building Materials, 172, 272-292

Vegas, I., Broos, K., Nielsen, P., Lambertz, O., \& Lisbona, A. (2015). Upgrading the quality of mixed recycled aggregates from construction and demolition waste by using near-infrared sorting technology. Construction and Building Materials, 75, 121-128

Wagih, A. M., El-Karmoty, H. Z., Ebid, M., \& Okba, S. H. (2013).Recycled construction and demolition concrete waste as aggregates for structural concrete. Housing and Building National Research Center, 9, 193-200

Wan Ibrahim, M. H., Jamaludin, N., Irwan, J. M., Ramadhansyah, P. J., \& Suraya Hani, A. (2014). Compressive and Flexural Strength of Foamed Concrete Containing Polyolefin Fibers. Advanced Materials Research, 911, 489-493

Yaqub, J. M., \& Bukhari, I. (2007). Effect of Size of Coarse Aggregate on Compressive Strength of High Strength Concrete. Proceeding of the $31^{\text {st }}$ Conference on Our World in Concrete and Structures, Singapore

Zhu, Y. G., Kou, S. C., Poon, C. S., Dai J. G., \& Q. Y. Li, Q. Y. (2013). Influence of saline-based water repellent on the durability properties of RAC. Cement and Concrete Composite, 35, 32-38 